\title{
ECOPRINT WUJUD EKONOMI KREATIF BERBASIS WIRAUSAHA DAN KEARIFAN LOKAL DUSUN KEKEP, PARAKAN, TEMANGGUNG
}

\author{
Astiwi Kurniati ${ }^{1)}$, Rio Mahardika ${ }^{1)}$, Irin Febri Ikhtiarawati ${ }^{1}$, Andrei Surya Darma ${ }^{1)}$, \\ Salistina Ayu Rizqi'), Vivi Nuraini' ${ }^{2)}$ \\ ${ }^{1) B i m b i n g a n ~ d a n ~ K o n s e l i n g, ~ F K I P, ~ U N I M M A, ~ M a g e l a n g, ~ J a w a ~ T e n g a h, ~ I n d o n e s i a ~}$ \\ ${ }^{2)}$ Manajemen, FEB, UNIMMA, Magelang, Jawa Tengah, Indonesia \\ Corresponding author: Astiwi Kurniati \\ E-mail : astiwi14@ummgl.ac.id
}

Diterima 21 Desember 2020, Direvisi 08 Februari 2021, Disetujui 09 Februari 2021

\begin{abstract}
ABSTRAK
Produk lokal merupakan salah satu kearifan yang ada di beberapa daerah yang dapat dijadikan sebagai ciri khas daerah tersebut. Dari banyaknya produk lokal yang ada di Dusun Gunung Kekep, Parakan Temanggung, ecoprint merupakan produk lokal unggulan yang menjadi ciri khas dusun tersebut. Ecoprint merupakan proses mendesain atau membatik dengan bahan alami. Bahan alami yang dapat digunakan dalam proses Ecoprint seperti dedaunan dan batang tumbuhan yang banyak mengandung zat tanin seperti daun potroseli, jenetri, jati, bunga marenggo, daun lanang, kayu secang yang sangat mudah ditemukan di Dusun Gunung Kekep, Parakan, Temanggung. Proses produksi ecoprint ini sangat ramah lingkungan, sehingga tidak menganggu ekosistem lingkungan sekitar. Para pengrajin ecoprint di dusun Gunung Kekep, Parakan Temanggung ini terwadahi dalam Kelompok Usaha Bersama (KUB) JENY 3, yang keberadaannya sangat membantu proses produksi ecoprint. Salah satu tujuan dari tim Pengabdian Pada Masyarakat (PPMT) Universitas Muhammadiyah Magelang bekerjasama dengan KUB JENY 3 adalah memberikan pendampingan teknik pewarnaan alami ecoprint, strategi pemasaran serta model kemasan (packaging) yang menarik, sehingga hasil produksi dari KUB JENY 3 memiliki nilai jual tinggi. Evaluasi dari kegiatan ini adalah melakukan Focus Group Disscussion (FGD) secara periodik dengan mitra dan perangkat dusun.
\end{abstract}

Kata kunci: produk; pemasaran; pengemasan.

\begin{abstract}
Local products are one of the wisdom that exists in several regions that can be used as a characteristic of these areas. Of the many local products available at Dusun Gunung Kekep, Parakan Temanggung, ecoprint is a superior local product that characteristic of that village. Ecoprint is the process of designing or making batik with natural materials. Natural materials that used for ecoprint process such as leaves and plant stems which contain lots of tannins such as potroseli leaves, jenitri, teak, Marengo flowers, lanang leaves, secang wood which are very easly to find at Dusun Gunung Kekep. Parakan, Temanggung. The ecoprint production process is very environmentally friendly, so it doesn't disturb the surrounding ecosystem. The eco print craftsmen in Gunung Kekep hamlet, Parakan Temanggung are included in the JENY 3 Joint Business Group (KUB), whose existence greatly helps the ecoprint production process. One of the goals from Muhammadiyah Magelang University Community Service (PPMT) team in collaboration with KUB JENY 3 are to assist with ecoprint natural coloring techniques, marketing strategies and attractive packaging models, so that the production results from KUB JENY 3 have a high selling value. The evaluation from this activity is to do a Focus Group Discussion (FGD) periodically with partners and Dusun apparaturs.
\end{abstract}

Keywords: product; marketing; packaging.

\section{PENDAHULUAN}

Dusun Gunung Kekep merupakan salah satu daerah yang berada di Parakan, Temanggung. Memiliki ketinggian 853 meter dari permukaan laut dan beriklim tropis dengan suhu rata-rata 25 - $30 \mathrm{C}$ serta ditunjang oleh dua musim yaitu kemarau dan penghujan.
Jumlah penduduk di Dusun Gunung Kekep ini berkisar 618 jiwa dan terbagi menjadi 4 rukun warga.

Peran domestik sangatlah dekat dengan perempuan. Peran domestik adalah peran dimana perempuan melakukan aktivitas di dalam rumah tangga. Apapun alasannya 
perempuan yang menjalani peran domestik tetap berhak mendapatkan pemberdayaan atau kesempatan untuk berkembang. Perempuan yang memilih peran domestik sebenarnya bekerja 24 jam namun seiring anak masuk sekolah atau bekerja maka perempuan yang memilih peran domestik tersebut akan memiliki waktu luang yang dapat dimanfaatkan untuk kegiatan usaha yang akan menambah penghasilan keluarga (Prapti \& Trimeiningrum, 2007)

Hal tersebut juga terjadi pada sebagian perempuan di dusun Gunung Kekep, Parakan Temangung, mereka mengembangkan produk lokal khas daerah yaitu ecoprint. Ecoprint sendiri berasal dari kata eco (ekosistem atau alam) dan print artinya mencetak.Sehingga dapat diartikan bahwa ecoprint adalah proses membatik dengan cara mencetak menggunakan bahan-bahan yang terdapat di alam sekitar sebagai kain, pewarna, maupun membuat pola motif. Bahan yang digunakan berupa dedaunan, bunga, batang, kayu maupun ranting.Pembuatan ecoprint sangat bergantung pada ketersediaan buhan alami yang digunakan sebagai dasar bahan banku utama(Saptutyningsih \& Kamiel, 2019). Jumlah pengrajin ecoprint di dusun Gunung Kekep ada 10 warga, rata-rata dapat menghasilkan sekali produksi 10 sampai 20 potong. Pengrajin ecoprint di dusun Gunung Kekep tergabung dalam KUB (Kelompok Usaha Bersama) JENY3. Melalui KUB JENY3 pengrajin terfasilitasi dari bahan berupa kain, alat produksi dan sebagian bahan pewarnaan alami (kayu, dedaunan, bunga maupun ranting) yang apabila anggota KUB ingin mengembangkan pola yang lain maka mencari bahan pewarnaan di sekitar lingkungan dusun Gunung Kekep.

Tingkat kesadaran dan pemahaman warga terkait pengembangan ekonomi kreatif berbasis kearifan lokal yang belum ada berdampak pada produksi, pemasaran maupun pengemasan (packaging). KUB JENY3 masih fokus pada produksi dan belum merambah pada pemasaran maupun usaha pengemasannya. Berbagai rupa produk dari KUB JENY 3 seperti kain $2 \mathrm{~m}$ sebagai bahan baju, tas, sarung bantal kursi, dompet, tas laptop dengan harga yang bervariatif berkisar Rp.150.000 sampai Rp. 350.000 (menyesuaiakan jenis produknya). Jumlah anggota KUB JENY 3 yang masih sedikit berimpas pula dengan jumlah produksi sehingga belum maksimal dalam pelayanan order atau pesanan dari konsumen. Begitu pula permasalsahan pemasaran yang masih sangat sederhana. Produk JENY 3 belum memasarkan secara online maupun penyediaan ruang untuk display sehingga produk dapat dikenal masyarakat luas, selama ini pemasaran hasil produksi hanya dari mulut ke mulut. Tidak hanya terkait proses produksi maupun pemasaran namun juga untuk pengemasan dari produk ecoprint belum memiliki kemasan yang menarik sehingga nantinya dapat menambah nilai jual produk tersebut. Pengemasan (packaging) merupakan proses yang berkaitan dengan perancangan dan pembuatan wadah (container) atau pembungkus (wrapper) untuk suatu produk (Syamsudin, Wajdi, M. Farid Praswati, 2012). Adapun tujuan kegiatan ini adalah membantu masyarakat dusun Gunung Kekep Parakan Temanggung yang tergabung dalam KUB JENY 3 untuk dapat mengembangkan usaha Ecoprint sebagai icon produk lokal yang memiliki nilai jual tinggi. Kegiatan ini meliputi teknik pewarnaan, strategi pemasaran sampai pengemasan produk (packaging).

\section{METODE}

Berbagai permasalahan yang dihadapi warga di Dusun Gunung Kekep Temanggung khususnya pengembangan produk lokal Ecoprint diupayakan untuk dapat ditindaklanjuti oleh tim Program Pengabdian Pada Masyarakat Terpadu (PPMT) Universitas Muhammadiyah Magelang. Program Pengabdian Pada Masyarakat Terpadu (PPMT) merupakan suatu program pengabdian pada masyarakat yang dilaksanakan secara terintegrasi antara dosen dengan kelompok mahasiswa yang diselenggarakan oleh Lembaga Penelitian dan Pengabdian kepada Masyarakat (LPPM) Universitas Muhammadiyah Magelang. Kegiatan pendampingan ini diikuti oleh tim mitra berjumlah 25 warga dusun Gunung Kekep Parakan Temanggung. Adapun metode penyelesaian permasalahan pengembangan produk lokal yang kami tawarkan mengacu pada pendapat Morelli (2015) yaitu pendidikan masyarakat, konsultasi, dipusi ipteks, pelatihan mediasi, simulasi ipteks, subtitusi ipteks dan advokasi. Namun demikian tim PPMT Universitas Muhammadiyah Magelang belum dapat menerapkan seluruhnya. Adapun proses penyelesaian yang dilakukan tim PPMT di dusun Gunung Kekep, Parakan Temanggung sebagai berikut:

Pendidikan Masyarakat : memberikan edukasi kepada masyarakat akan pentingnya pengembangan ekonomi kreatif dalam hal ini pengoptimalan produsk lokal ecoprint sebagai usaha bersama yang akan menambah tingkat perekonomian masyarakat di dusun Gunung Kekep pada umumnya dan otomatis akan menambah income bagi keluarga.Salah satu kegiatan pada tahap pendidikan masyarakat ini adalah memberikan pelatihan teknik pewarnaan dan desain alami ecoprint. 


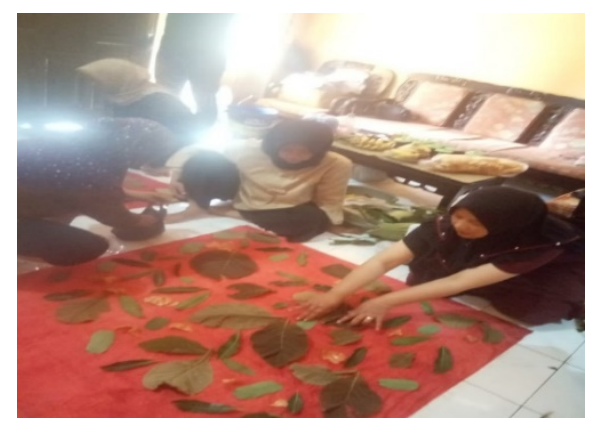

Gambar 1. kegiatan teknik pewarnaan dan desain

Dipusi Ipteks: merupakan proses dimana adaptasi teknologi baru menyebar luas di masyarakat. Adaptasi teknologi ini dapat lahir dari rumah tangga maupun industry. Dipusi ipteks yang tim PPMT Universitas Muhammadiyah Magelang lakukan adalah memberikan pengetahuan teknologi sebagai media dalam pemasaran ecoprint. Pada kenyataannya pemasaran yang dilakukan dengan menggunakan teknologi khususnya teknologi informasi akan sangat membantu proses pemasaran sehingga produk lokal ecoprint dusun Gunung Kekep Parakan Temanggung dapat dikenal lebih luas.

Pelatihan: pelatihan merupakan kegiatan yang tepat dalam mengembangkan sebuah usaha. Pelatihan kewirausahaan, soft skill akan sangat membantu dalam menumbuhkan etos kerja, menumbuhkan kreativitas, daya juang tinggi ketika harus berhadapan dengan kompetitor serumpun. Pada pelatihan ini warga dusun Gunung Kekep khususnya anggota KUB JENY 3 dan remaja yang tergabung dalam Karang Taruna memperoleh pengalaman langsung yang diawali dari mengubah mindset tentang pengelolaan wirausaha yang benar sampai bagaimana harus menampilkan hasil produk dalam bentuk kemasan (packaging) yang menarik.

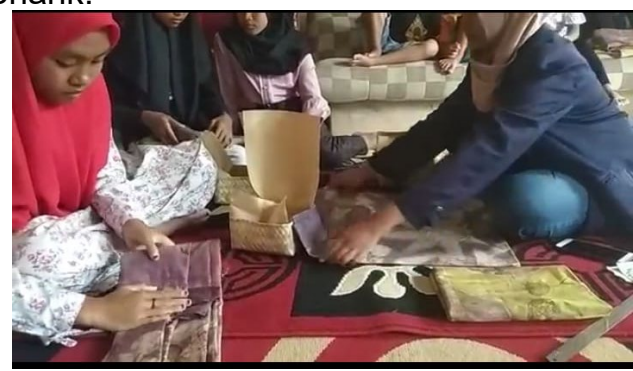

Gambar 2. Pelatihan Packaging Ecoprint

Simulasi Ipteks: pada kegiatan simulasi ini peserta yang terdiri dari anggota KUB JENY 3 dan sebagian remaja yang tergabung dalam Karang Taruna di damping praktek secara langsung bagaimana mengoperasionalkan teknologi informasi dalam hal ini gawai atau smartphone sebagai media untuk mempublikasikan produk lokal ecoprint ke masyrakat luas dalam bentuk praktek penggunaan online shop dan media sosial.

\section{HASIL DAN PEMBAHASAN}

Permasalahan dalam pengembangan produk lokal seringkali dipengaruhi oleh beberpa faktor. Pendanaan atau modal, sumber daya manusia, maupun akses pemasaran produk.upaya untuk meningkatkan pengembangan produk lokal di dusun Gunung Kekep, Parakan Temanggung sebenarnaya dapat dilakukan melalui pemberdayaan ibu-ibu di dusun yang tergabung dalam PKK. Upaya untuk meningkatkan kemampuan dengan pemberdayaan masyarakat dimana dasarnya meupakan kegiatan melalui program peningkatan kapasitas orang terutama kelompok lemah atau kurang beruntung agar memiliki kemampuan dalam memenuhi kebutuhan dasarnya mengemukakan gagasan, melakuskan pilihan hidup, melaksanakan kegiatan ekonomi, menjangkaus dan memobilisasi sumber serta berpartisipasi dalam kegiatan social (Zubaedi, 2013).

Produk lokal ecoprint dari dusun Gunung Kekep, Parakan Temanggung yang tergabung dalam KUB JENY 3 termasuk sebagian besar usaha kecil dan rumah tangga dari sub sector manufaktur yang sama diharapkan akan membentuk jaringan dan mengelompok secatra spasial yang nantinya akan disebut klister atau industry district. Sedangkan menurut Marshall (Kuncoro, 2007) industrial district sebagai suatu klister produksi yang terspesiakisasi secara geografis dan mewakili industry tradisional yang umumnya ada di dusun atau pedesaan.

Pengembangan produk lokal ecoprint yang dikembangkan di dusun Gunung Kekep Parakan Temanggung selain melalui sosialisasi, pendampungan dan pelatihan dengan melakukan 1). Membuat produk lokal yang memiliki kekhasan tersendiri/trade mark daerah 2). Ketersediaan infrastruktur, SDM, teknologi dan modal 3). Adanya kemitraan, dukungan kebijakan dan kelembagaan 4). Analisa dampak terhadap lingkungan 5). Tingkat daya saing. Hal tersebut merupakan identifikasi unggul tahap awal dalam perencanaan pembangunan ekonomi local seperti yang dikatakan oleh Blakely and Bradshaw (2002) dalam bukunya planning local economic development.(Sandriana et al., 2015).

Sehingga apabila semua komponen di lingkungan dusun Gunung Kekep, Parakan temanggung dapat bersinergi dan membuat link kerjasama baik dari sektor swasta maupun pemerintah setempat maka akan mudah dalam 
pengembangan usaha produk lokal. Selain itu di dusun Gunung Kekep sendiri sangat berlimpah sumber daya alamnya yang sangat mendukung pengembangan produk lokal dalam hal ini ecoprint.

\section{SIMPULAN DAN SARAN}

Kegiatan Pengabdian Pada

Masyarakat Terpadu (PPMT) Universitas Muhammadiyah Magelang di Dusun Gunung Kekep, Parakan Temanggung diharapkan tidak hanya sebagai kegiatan formalitas akademik saja tetapi melalui kegiatan Pengabdian Pada Masyarakat Terpadu (PPMT) diharapkan dapat mengembangkan dan memajukan warga dusun melalui kegiatan pendidikan, sosialisasi, pelatihan dan pendampingan yang sudah dilakukan. Khususnya dalam pengembangan produk local dalam hal ini adalah ecoprint melalui kegiatan PPMT ini diharapkan semakin banyaknya produk yang dihasilkan, pemasaran yang lebih luas dengan pengguanan teknologi informasi melalui konsep online shop, Instagram (IG) sehingga produk dapat terpublikasi secara luas. Selain produksi dan pemasaran tak kalah penting adalah kemasan/packaging yang akan sangat mempengaruhi daya beli. Kemasan yang menarik dan bernuansa kekhasan dapat dijadikan sebagai media promosi bagi masyarakat di luar dususn Gunung Kekep, Parakan Temanggung.

\section{UCAPAN TERIMAKASIH}

Kami tim Pengabdian Pada

Masyarakat Terpadu (PPMT) Universitas Muhammadiyah Magelang megucapkan terima kasih kepada semua pihak yang telah mendukung dan berpartisipasi aktif dalam pelaksanaan program kerja di dusun Gunung Kekep, Parakan Temanggung. Kami berharap program rintisan yang telah tim dan masyarakat dusun kembangkan akan dapat menjadi program unggulan di dusun Gunung Kekep, Parakan Temanggung. Kerjasama diupayakan tidak hanya sebatas pada kegiatan PPMT, tetapi dapat di lanjutkan pada program maupun kegiatan yang lain sehingga pengembangan produk local dapat terwujud.

\section{DAFTAR RUJUKAN}

Kuncoro, Mu. (2007). Otonomi dan Pembangunan Daerah: Reformasi, Perencanaan, Strategi dan Peluang. Erlangga.

Morelli, N. (2015). Challenges in Designing and Scaling up Community Services. Design Journal, 18(2), 269-290. https://doi.org/10.2752/175630615X1421 2498964394
Prapti, M. S., \& Trimeiningrum, E. (2007). Pengembangan Ketrampilan Ecoprint Sebagai Alternatif Pemberdayaan Kelompok Dasa Wisma Melati 2 Ungaran. Proseding Seminar Nasional Hasil Pengabdian Kepada Masyarakat, 4(1), 544-548.

Sandriana, N., Hakim, A., \& Saleh, C. (2015). Strategi Pengembangan Produk Unggulan Daerah Berbasis Klaster di Kota Malang. Reformasi, 5(1), 89-100.

Saptutyningsih, E., \& Kamiel, B. P. (2019). Pemanfaatan Bahan Alami untuk Pengembangan Ecoprint dalam Mendukung Ekonomi Kreatif. Prosiding Seminar Nasional ..., 2, 276-283. http://prosiding.unimus.ac.id/index.php/se mnas/article/view/396

Zubaedi. (2013). Pengembangan Masyarakat, Wacana dan Praktik. Kencana. 